DOI: 10.4312/an.51.1-2.63-70

\title{
Hate Speech and French Mediaeval Literature
}

\section{Miha Pintarič}

\section{Summary}

Hate speech is spoken or written word which expresses a hostile attitude of a dominating majority towards any kind of minority. The author analyses a few examples of hate speech in literary history and concludes that such a phenomenon is typical of The Song of Roland, whether uttered in a direct way or spoken between the lines. One will expect hate speech in epic and heroic poetry, less in the Troubadour poetry. Yet we come across this awkward characteristic even in their love poetry. To be quite clear, in the poetry of Bernart de Ventadorn. The last part of the article is about the courtly romance. The author concludes that hate speech can only be controlled by love, not any, but the love that makes one a better person, and which the Troubadours called fin'amors.

Key words: hate speech, epics, troubadours, courtly romance, middle ages 
Hate speech is spoken or written word which expresses a hostile attitude of a dominant majority to some kind of minority (minorities, indeed, do not openly attack the majority, and if they do, one should have a look into what they really are). The majority vs minority relationship can be defined in terms of legal power, ideology (religious, racial), money, social status or, simply, number. The limits between 'majority' and 'minority' are rather vague, this is why any precise definition will be impossible in such cases, and the meanings of the respective expressions most relative; for a would-be marginal (group), well endowed with funds, can buy himself (herself or itself) a way to power, and exercise an equivalent kind of tirany he, she or it has been complaining to be a victim of. This is quite possible though not necessary. Numbers are not decisive since »statwistics« will serve you in any position.

Hatred will be percieved by the target persons or taget groups as unjustified, and hate speech will be experienced as threatening. In other cases, 'hate speech' works under cover (Shakespeare, as always, is a treasury of examples: Iago is one of a hypocrite trying to make the best out of his situation of a marginal whose intentions are pernicious (Othello); another, Antony (Julius Caesar III, ii), delivers a speech to get moral satisfaction - and, in fact, much more than that - from an apparently lost cause, by his art of rhetorics: a minority thus overpowers a majority and puts itself in its place; Iago is vicious and will be punished while Antony, pursuing a just and noble cause, will be rewarded. Shakespeare believes in some universal moral order, just as mediaeval and most renaissance authors do). (Yates)

The expression of hatred is universal, so much so that one does not have to understand the meaning of what is being said for a discourse to be qualified as 'hate speech'; ${ }^{1}$ non-linguistic markers may be enough for him (or her) to realise he or she had better bundle up his or her belongings and vanish into thin air while he or she still can. A few well-known examples of hate speech are Hitler and Gobbels's anti-Jewish addresses, communist ideological discourse which preceded the physical elimination of their then ideological opponents (and with them, many who were in fact not); Tito's speech from the balcony of the University of Ljubljana was typical, as well as this locus verecundiae itself; the speeches that spawned the latest Balkan wars: the memorandum of the members of Serbian Academy, Milošević's infamous 'Ne čujem dobro!' - 'I cannot hear you!', and his address at Ušće, with an attendance of one million). Others speak in silence.

Everything exists in opposites. Pre-socratics thought so, and Hegel did. Hatred has its opposite, and so has hate speech. Love as the opposite of hate should

1 To me everything uttered by the North Corean news presenter is hate speech although I do not understand a word of Corean. 
produce 'love speech'. It is very doubtful, though, that the crowd listening to words of love and peace being delivered in a voice which exceedingly reminds one of barking, will get the message. It rather feels that there is not much difference between 'love speech' and 'hate speech', if there is any between love and hate. Hate produces hate speech even if it uses the 'opposite' discourse, the words of love. It does not have to change the words, not even their meaning, only their sense. The problem, however, is also terminological. While it is pretty clear what one means by 'hate', it is not so with 'love'. From human to divine, from passionate to charitable, the variety of choice is surprising, and so is the nature of different kinds of'love'. Hate speech is not, here, Catullus' Odi et amo, or a troubadour song descending from the heights of a quasi-mystical experience (the likeness is very strong), it is not psychologically grounded or 'individual', hate speech refers to a group, or an individual only as a member of that group. Hate (speech) will therefore mean something like the opposite of 'charitable love' (speech) as a secular ideal, that of Jean de Meung, for instance. Essentially, it has nothing to do either with the love of God, or with the Salvation Army. Social markers of hate speech can be stronger than its rhetorical markers.

Hate speech is often not grounded in any real circumstances, but even when it is, it is unethical and should not be perpetrated. In the Middle Ages, the 'hatespeech' label did not exist although the thing itself did. The reality was interpreted dualistically, as black and white rather than in full colour. Feelings were stronger, especially those of shame and guilt (someone else's, preferably), as well as other moral categories. Hate speech addresses fear. As such, it is universal, even animals understand it to a degree similar to humans.

\section{THE SONG OF ROLAND (LA CHANSON DE ROLAND)}

There is no unrequited hate in the Song of Roland, which can itself be read (or listened to as it used to be) as one long hate speech. Everybody hates everybody, exceptions are few (among those are Charlemaine and Roland, Roland and Oli ver...). Charlemaine hates Marsile, and the feeling is reciprocated, only Marsile has deceitful intentions which Charlemaine has not. Every soldier in one army hates every soldier in the other army without having ever met him (not her). As if it was not enough, there are factions that hate each other, which is even more evident on the Christian side (Ganelon and Roland, for example). The 'commanding officers' rather like the idea supported by Ganelon:

To your misfortune will you listen to a fool ... little he cares by what death we die. It is not right that a counsel of pride proceed any further; let us leave the fools and listen only to the wise. (Roland 2/15) 
Ganelon has had enough of warfare and would like to return home. But Roland, no. He knows he has a mission to complete, he can see right through the changing world and grasp the essence of things. He finds no listening ear, though. When Roland suggests Ganelon should be the messenger to the king Marsile, which is as much as being doomed to a bitter end, Ganelon's discourse changes to hate speech, and Roland's immediately after that.

When Ganelon sees that now Roland is mocking him, his mortification is so great that he nearly bursts with anger. His senses almost leave him, but he says to the count: 'Indeed, I have no cause to love you; you have brought an unjust judgment on me...' (Roland 7-8/22-23)

The situation becomes even more complicated after Ganelon suggests Roland should lead the rearguard. These men are soldiers, surely, and they should be ready to fight and die. Even so, not all of them are to the same degree eager to die. These soldiers need not hate every particular enemy (although hate probably helps in battle). Roland is hoping enough of them would grasp the situation from his point of view to continue the conquest. In 'modern' view, Roland is the main perpetrator of hatred in the Song with his name in the title. The mediaeval viewpoint of hate speech, however, may be more pragmatic, meant either as a functional address before combat, a motivation and an ideological simplification with the purpose of reducing the enemy's human side and make it ethically acceptable to kill him (her?). It recalls the incident which occurred at Saint Eustache in Paris, when the two factions of pretenders to the throne, the Armagnacs and the Bourgignons, fell out with each other, or rather, the Armagnacs were ambushed and slaughtered, then roses were strewn over the corpses to neutralise the stench.

A variety of paradoxical hate speech is also an 'insult' which produces an ambiguous impact (but which all the heroes of The Song of Roland generously give away to their enemy) :

... essayant de ravaler autrui au rang de non-locuteur (d'où le recours à des termes d'adresse dépréciatifs de type non-humain / plus ou moins animé), le code utilisé pour ce faire reste néanmoins éminemment humain, dans le sens où le langage ne peut s'adresser qu'à un autre locuteur ... l'insulte [est] un acte de langage à prendre en compte dans les rituels de solidarité ... (Lagorgette 330)

\section{THE TROUBADOUR POETRY}

If there is a safe haven in the ocean of mediaeval literary hate speech, it ought to be the troubadour poetry. But is it really? Certainly not. Not only Bertran de Born 
and the likes of him were past masters of hate speech, engaging their feudal lords in battling against each other or against a third party, and ending up in Dante's

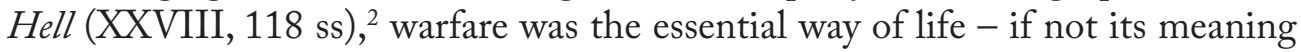
- of these noblemen who lived on the ideal as contradictory as the joven, spending in profusion what they did not have and then restoring it by making violence to the other. Hate speech can be found in the very cansós, 'chansons d'amour'-

S'eu en volgues dire lo ver, eu sai be de cui mou l'enjans:

d'aquelas c'amon per aver.

E son merchandadas venaus!

Messongers en fos eu e faus!

Vertat en dic vilanamen;

E peza me car eu no.n men! - ,

just as in the sirventès with all kinds of topic, preferably war and military campaigns, or just plunder. It is the sublime 'chantre d'amour', Bertran de Ventadorn, though, who calls the fair sex, well, some of them, 'merchandadas venaus' - in a cansó... If this is not hate speech, let me know what hate speech is. (Hamlin 103)

\section{COURTLY ROMANCES}

French courtly romances are texts impeccable in terms of politeness and respect of the courtly code of conduct. Courtly heroes may sometimes yield to the temptation and satisfaction of putting the other in a position of the underdog, this is nevertheless the least typical of their genre. There is violence, yes, and the whole feudal world is founded on the principle of violence, i.e. the reinforcement of the will of the stronger. Which is done by the application of an individual's power (his own or his army's). Courtly romances are full of violence although not in the same way as epic poetry since violence is not in the centre of attention and is rarely spoken of in a direct way (besides, it is always an individual who makes it and an individual who takes it).

In Chrétien de Troyes' Erec and Enide, Enide tells her husband of the rumors about him, namely, people are saying that he has withdrawn from chivalric life because he has found too much happiness in his marriage. He has become a recreanz, which is amost as much as a coward. Erec suddenly becomes rude to his wife and

2 Indeed, G. Guiran, in an article on Bertran de Born, states that the violence and its terminology in the poetry of this poet are not to be understood as his own, individual, property', but as »la cérémonie collective dans laquelle la classe aristocratique des guerriers trouve la justification de son existence«. (Guiran 247) 
stops even speaking to her. It is obvious that in this case, silence has taken the role of hate speech, which the situation calls for though the temporary animosity of Erec towards Enide never gets as far as to be expressed properly. Characters other than Erec or Enide speak with hostility not so often to them but about them, i.e. indirectly.

The count, continuing to rail at Erec, could he be attained, made threats he would not be restrained from promptly having Erec's head.

Directly, he addresses the men of the posse chasing Erec:

'May that man's future fate be dread Who fails to spur with all his might! The man who can behead the knight And give me one I so detest I shall consider serves me best.

(Erec pp. 103-104)

Another villain count, Oringle, is even worse, he beats Enide - and what kind of knight is a knight who beats women ? - but never really directly addresses her by using 'hate speech'. ${ }^{3}$

Hate is the opposite of love. Philosophically, and particularly in the Middle Ages, Love means 'being' while hate corresponds to 'non-being.' Hate is evil, love is good (this is a very generalised statement which may sometimes prove wrong but is true on the whole). Since evil is nothing, hate speech is a vehicle for nothing. The supreme Good is the aim of all human aspiration and, at the same time, the universal flow of goodness. Hate speech is the effort evil opposes to this flow in order to stop it. Evil cannot win but it does cause a great deal of grief. To say that evil is nothing, in this sense, disregards entirely the individual and his (or her) desires, plans, frustrations, tragedies etc. They are indeed so small when looked at from a distance that they seem not to have any real existence at all. They do, however, have an existence, as 'small' as it may be. They do matter, just as global or cosmic events do, or more.

'Nothing will come of nothing' - the word of king Lear is prophetic. Whoever does not give love, gives nothing and will get nothing. Let us just think of the troubadours and one of their key values, 'donars', for which Marcabru says it is the brother of 'jovens'! The youth gives without thinking twice. Since it has no

3 On violence, but not hate speech, see also M. Pintarič. 
wealth, it is generous in giving itself, which is a spiritual gift when given and understood properly. And whoever is ready to kill for possession will lose even what he (or she) has got. Courtly romances and epic poetry offer enough examples. Whoever has patiently renounced everything without ulterior motive, will get it all. Miracles and different stories support it. (Jongleur) For renouncement leads to transformation, and transformation to conversion. There is 'transformation' in the Song of Roland, in its most rude form since it is forced upon candidates by threats. But there is one in the Chevalier au barisel (The Knight with a barrel), and it is a conversion most 'organic', one is tempted to say, although it may not look so. It happens by the grace of God. One tear fills up the whole barrel, and the knight is saved... (on conversion in mediaeval poetry, see Poésie)

And what has all this got to do with hate speech? This is precisely what the last example should clarify: renouncing hate speech, even if it is only replaced by silence, the 'good' silence, may be the first step towards integrating the flow of good that holds up the universe. One does not even have to renounce it, he (or she) can just forget about it (which regularly happens in states of modified consciousness, like when falling in love - amors melhura, said the troubadours over and over again, did they not?). Love of whatever sort sholuld make one a better person if it is true. And there will be no need for hate speech ever again.

\section{BIBLIOGRAPHY}

The Song of Roland, translated byJessie Crosland, In parentheses Publications, Old French Series, Cambridge, Ontario 1999, http://www.yorku.ca/inpar/roland_ crosland.pdf .

Erec and Enide, translated by Ruth Harwood Cline, Athens \& London, Georgia UP, no date.

Guiran, G., »Bertran de Born, troubadour de la violence?«, La violence dans le monde médiéval, CUERMA, Aix-en-Provence, 1994, pp. 235-253.

Hamlin, F. R., P. T. Ricketts, J. Hathaway, Introduction à l'étude de l'ancien provençal. Textes d'étude, Droz, Genève, 1967.

Lagorgette, D., »Termes d'adresse, acte perlocutoire et insultes: la violence verbale dans queleques textes des $14^{\text {ème }}, 15^{\text {ème }}$ et $16^{\text {ème }}$ siècles «, La violence dans le monde médiéral, CUERMA, Aix-en-Provence, 1994, pp. 317-332.

Pintarič, M., »Le rôle de la violence dans le roman médiéval: l'exemple d"'Erec et Enide' ", La violence dans le monde médiéval, CUERMA, Aix-en-Provence, 1994, pp. 415-423 and »The role of violence in the romances of Chrétien de Troyes«, Acta neophilologica, 2007, 40, 1/2, pp. 167-175 (a translated and updated version). 
Yates, F., The Art of Memory, Chicago UP, 1966, 400 pp.

Zink, M., Le jongleur de Notre-Dame, Seuil, Paris, 1999.

Zink, M., Poésie et conversion au Moyen Âge, Paris, PUF, 2003.

Miha Pintarič

University of Ljubljana miha.pintaric@ff.uni-lj.si

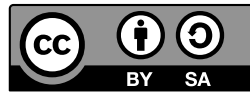

\section{Discours de haine et la littérature française du Moyen Âge}

Discours de haine est parole proférée ou écrite qui exprime une attitutde hostile de la majorité dominante envers une minorité quelconque. Après avoir analysé quelques exemples de'discours de haine' de l'histoire (littérarire) plus où moins récente, l'auteur trouve que ce discours, soit exprimé directement soit sous-entendu, est typique de la Chanson de Roland. On s'attendait, d'ailleurs, au discours de haine dans la poésie épique, ce qui nétait pas le cas de la poésie des troubadours. Même là, cependant, on rencontre cette attitude gênante, et non uniquement dans les sirventès (chansons des serviteurs, chantant des valeurs morales etc.), dans la chanson d'amour (cansò), pareillement. Non uniquement chez Bertran de Born, dans la poésie de Bernart de Ventadorn également. Le dernier passage porte sur le roman courtois avant de conclure que l'on ne peut maîtriser le 'discours de haine' que par l'amour, dans le sens dynamique, un amour qui rend l'homme meilleur.

Mots clés : discours de haine, épopée, troubadours, roman courtois, moyen âge

\section{Sovražni govor in francoska srednjeveška književnost}

Sovražni govor je govorjena ali pisana beseda, ki izraža sovražni odnos prevladujoče večine do kakršne koli manjšine. Avtor analizira nekaj primerov sovražnega govora v bolj ali manj sodobni (literarni) zgodovini in ugotovi, da je takšen govor, bodisi neposredno bodisi med vrsticami, značilen za Pesem o Rolandu. Sicer pa je avtor pričakoval sovražni govor v epski poeziji, manj pa $\mathrm{v}$ trubadurski. Vendar tudi tam naletimo na to nerodno značilnost, in ne samo v sirventezi (pesmi, ki jih pojejo oprode in opevajo moralne vrednote etc.), prav tako v kanconi, ki je vendarle ljubezenska pesem. In to ne le pri Bertranu de Bornu, temveč celo v pesmih Bernarta de Ventadorna. Zadnji del članka tematizira dvorski roman in sklene $\mathrm{z}$ mislijo, da lahko sovražni govor obvladamo samo $\mathrm{z}$ ljubeznijo, in sicer s takšno, ki naredi človeka boljšega, to pa je fin'amors.

Ključne besede: sovražni govor, epska poezija, trubadurji, dvorski roman, srednji vek 